\title{
Different Applications of Sulphur Oxidizing Bacteria: A Review
}

\author{
Suman Chaudhary*, Tanvi, Rinku Dhanker and Sneh Goyal \\ Department of Microbiology, CCS Haryana Agricultural University Hisar, \\ Haryana-125004, India \\ *Corresponding author
}

\section{A B S T R A C T}

\section{Keywords}

Crops, Bioleaching, bacteria, Sulphur, gypsum, Anhydrite, Epsomite, Iron pyrite

Article Info

Accepted:

07 October 2019

Available Online:

10 November 2019
Sulphur is an essential nutritional element for plants, animals, microorganisms and humans; as it is integral component of many compounds including protein. Sulphur is metabolized into different forms with the help of sulphur oxidizing bacteria, which use sulphur as energy producing ingredient. Sulphur oxidizing bacteria have an interesting property of adaptability in wide range of habitats. Due to this property they have many applications in different fields like for improving quality of crops, bioleaching and extraction of metals from ores, in waste water treatment plants, for removal of hydrogen sulphide gas, concrete bridge structure and for bioremediation etc.

\section{Introduction}

Sulphur (S) is an important component of organic matter. It is an essential macronutrient for plants, animals, microorganisms and humans. In both plants and humans, $\mathrm{S}$ comes after $\mathrm{K}, \mathrm{Ca}$ and $\mathrm{P}$ in abundancy (Scherer, 2009). It is found in amino acids, which are building blocks of protein. Sulphur is also part of many other biologically active molecules found in reduced forms (Tandon and Messick, 2002; Kertesz and Mirleau, 2004; Jamal et al., 2010). All living organisms have requirement of $\mathrm{S}$ as an elemental component. Sulphur is taken up mostly in the form of sulphate, with further reduced to sulphide to form further necessary compounds. The average amount of sulphur content found in organisms is up to $0.2 \%$ of dry weight though some organisms use $\mathrm{S}$ compounds higher amounts in many ways like for anabolic processes, reducing power (electron donor), source of energy or as electron acceptor (Camacho, 2009).

The source of sulphur in soils is mainly derived from the sulphur containing minerals found in parent materials and the plants and animals remains or from the addition of elemental $\mathrm{S}$ from outer sources. Sulphur is mostly found in the form of sulphates 
sulphides and organic fractions associated with nitrogen and carbon compounds. The important sulphur bearing minerals in rocks and soils are gypsum, anhydrite, epsomite, iron pyrite, sphalerite, chalcopyrite, galena and arsenopyrite. Sulphur mainly occurs in organic and inorganic forms and is cycled in between these forms via mineralization, mobilization, immobilization, oxidation and reduction processes (Jamal et al., 2010). S exists in all three phases i.e. solid, liquid or gaseous. Plants mainly take up sulphur in the form of $\mathrm{SO}_{4}{ }^{2-}$ and reduce it to form $\mathrm{S}$ containing amino acids and other compounds. In plants cysteine is the main source of sulphur for most of the other S-compounds. The recommended dose of dietary allowance for sulphur amino acids for humans is $14 \mathrm{mg}$ $\mathrm{kg}^{-1}$ of total bodyweight (Prasad, 2016).

\section{Extent of sulphur deficiency}

Sulphur is involved in the synthesis of amino acids and proteins, enzymatic and metabolic activities taking place in plants. S deficiency in soils and plants in leads to an inhibition of protein synthesis and also results in accumulation of non-S containing amino acids particularly asparagine, glutamine and arginine in plant tissues. The deficiency of sulphur in areas is seen more where high $\mathrm{S}$ utilizing crops like oilseeds and pulses are grown regularly. Approximately $41 \%$ of our Indian soils are deficient in sulphur and deficiency of $\mathrm{S}$ is developing fast in areas where, Intensive cropping system, taking high yielding varieties with use of high analysis chemical fertilizers particularly sulphur free Sfree fertilizers like diammonium phosphate and urea etc. are being used (Singh, 2001).

\section{Effects of sulphur deficiency}

Plants suffering from $\mathrm{S}$ deficiency resemble in symptoms in nitrogen deficiency as the leaves turned to light green or yellow in colour. The most common visible symptoms of sulphur deficiency in oilseed and leguminous crops generally seen on young foliage as pale chlorotic leaves, high red tints at leaf margins reduced nodulation, stunted growth, poor branching, thin slender stem etc. In cereal grains, stunted growth, delayed maturity, small and spindly with slender stalks are common symptoms. Hence, $\mathrm{S}$ is essential for plant nutrition and its shortage can really affect the yield and quality. In sulphur deficient plants greater decrease in chlorophyll content in leaves, inhibition of protein synthesis and carbohydrate metabolism, composition of proteins, supply of mineral nutrients, nitrogenase activity in root nodules etc. take place which ultimately affect the growth, yield and quality of crops and produces. For example, a decline in cysteine content of cereal grains like wheat further lessens the baking quality of flour because disulphide bridging of the gluten fraction is responsible for the polymerisation during doughing. In mustard family the content of glucosinolates is directly related with the supply of $\mathrm{SO}_{4}{ }^{2-}$. When Plants are grown at sites with low $\mathrm{S}$ supply, the breeding hybrid cultivars are more sensitive to $\mathrm{S}$ deficiency than the traditional crops. The deficiency may be due to the role of glucosinolates as transient storage of S-compounds (Shreeja, 2016).

\section{Toxic effects of sulphur}

$\mathrm{S}$ may be toxic to the plants due to high $\mathrm{SO}_{2}$ amount in the air. The critical level of $\mathrm{SO}_{2}$ for plants is $120 \hat{\mathrm{A}} \mu \mathrm{g} / \mathrm{m}^{3} \cdot \mathrm{SO}_{2}$ may be removed from the environment mainly by precipitation or direct contact of the gas particles with soil and vegetation in a process called dry deposition.

The amount of sulphur brought to the earth surface in precipitation form generally varies broadly at different places to other and is affected by many factors like by volume of 
precipitation (rainfall); industrial areas set up, proximity to sea and the usual winds out there. Although the amount of $\mathrm{SO}_{2}$ are numerous times higher than that of normal levels near industrial areas. The cause of Sulphur dioxide $\left(\mathrm{SO}_{2}\right)$ toxicity also due to its liberation from different sources. $\mathrm{SO}_{2}$ captivated by the vegetation mixes in the moist surfaces of mesophyll cells present in the stomatalvoids. The sulphurous acid $\left(\mathrm{H}_{2} \mathrm{SO}_{3}\right)$ forms from the reactions of $\mathrm{SO}_{2}$ dissociates giving rise to $\mathrm{H}^{+}$, $\mathrm{HSO}_{3}{ }^{-}$and $\mathrm{SO}_{3}{ }^{2-}$ and $\mathrm{SO}_{4}{ }^{2-}$ ions. Further the disruption of chloroplast membranes can also takes place due to sulphur dioxide toxicity. The availability of $\mathrm{SO}_{\mathrm{x}}$ along and $\mathrm{NO}_{\mathrm{x}}$ in the environments causes acid rains, which also damage the crop to a hugeextent(Shreeja, 2016).

\section{What are sulphur oxidizing bacteria?}

Sulphur bacteria forms many mutualistic interactions depending on the types of sulphur compounds, whether they interact with oxidized or reduced form. Though, direct interactions (physical contact/close trophic relationships) may also takes place. An example of stable structural association(most evolved symbiosis in prokaryotes) of green sulphur bacteria is with motile chemotrophic bacteria, which are responsible for syntrophic growth based on the exchange of inorganic and organic S-compounds.(Camacho, 2009)

The sulphur bacteria, which are having capability to oxidize the reduced forms of sulphur compounds with sulphate as a final product, are known as sulphur oxidizing bacteria (SOB). In nature Scycled (sulphur cycle) between many different biological forms, which takes place absolutely by the action of microorganisms. Sulphur is absorbed by plants in the form of $\mathrm{SO}_{4}{ }^{-2}$, which further undergoes a continuous conversion in series before its assimilation into the different Scompounds (Katyal et al., 1997). Sulphur oxidizing bacteria generally belongs to genus like Thiobacillus, Beggiatoa, Thiothrix, Thiomicrospira, Desulphuromonas and Achromatium (Das et al., 1996) but the oxidation process is not limited to the true sulphur bacteria; it takes place as well in the bacteria having heterotrophic mode. These sulphur oxidizing heterotrophic bacteria, belongs to the genera Pseudomonas, Escherichia coli, Alcaligens and Xanthobacte rand isolated from different environment (Starkey, 1935; Kuenen and Beudeker, 1982).

Two different kinds of metabolically active groups exist: one is obligate chemolithotrophic bacteria, which can utilize the oxidizable $\mathrm{S}$ compounds only (and $\mathrm{CO}_{2}$ as the source of carbon) and the other is heterotrophic, which may also follow the chemolithototrophic mode of nutrition (Chaudhary, 2018).

The typical examples of obligate chemolithotrophs, are Thiobacillus neapolitanus, Thiobacillus thioparus, Thiobacillus denitrificans (denitrifiers) and Thiobacillus thiooxidans (extreme acidophile). Some other examples of this group are Thiobacillus ferrooxidans (acidophilic ironoxidizer), Thiomicrospira and some species of Thiobacillus halophilus. The most common example of heterotrophs in this category include Thiobacillus acidophilus, Thiobacillus novellus, Paracoccus denitrificans, Thiobacillus aquaesulis (moderate thermophile), Thiobacillus intermedius, Xanthobacter tagetidis, $P$. versutus, Thiomicrospira thyasirae and Thiosphaera pantotroph (Kuenen and Beudeker, 1982). A number of chemolithotrophic and nonfilamentous sulphur oxidizing bacteria like Thiospira or Thiomicrospira, Sulfolobus, have also been isolated from some special environments (Starkey, 1934; Vidyalakshmi et al., 2009). 


\section{Sulphur oxidation in rhizosphere}

The soil environment surrounding plant roots is the zone of intense microbial activity. A large number of microorganisms capable of sulphur oxidation have been isolated from the root region of crop plants.

Shi et al., (2011) demonstrated a sulphur oxidizing strain HT1, isolated from rhizosphere of rice soil having $\mathrm{Pb}$ pollution, using thiosulphate as electron donor at $\mathrm{pH} 7.0$ and on the basis of 16S rRNA gene sequencing, the isolated strain found belonging to $\gamma$-proteobacteria, HaloThiobacillus.

Chaudhary et al., (2017) isolated three potential strains of sulphur oxidizing bacteria namely SSF7, SSA21, and SSS6 from rhizosphere of mustard, showing sulphate ion production concentration of $2.268,3.102$, and $2.785 \mathrm{mM}$ respectively. They were characterized as Xanthobacter, Pseudomonas and Pseudomonas sp. for SSF7, SSA21 and SSS6 respectively.

\section{Mechanism of sulphur oxidation}

The oxidation of reduced sulphur in soil is usually regarded as a microbial process (Katyal et al., 1997). Wide spectrums of microorganisms are capable of oxidizing sulphur. Microbial sulphur oxidation is, on the whole, beneficial to soil fertility, resulting in the formation of $\mathrm{SO}_{4}{ }^{2-}$, which can be used by the plants, while the acidity produced by process of oxidation is used to solubilize the other plant nutrients specially that of phosphorous and improve the alkaline soils (Wainwright, 1984). Most of the soil contains many sulphur oxidizing microbes and this number increases rapidly on sulphur addition (Swaby and Fedel, 1973). Skiba and Wainwright (1984) observed that following addition of elemental sulphur to a fertile loam soil, both thiosulphate and tetrathionate had transitory appearance whereas sulphate accumulated throughout the incubation period. These studies suggest that elemental sulphur is oxidized to sulphate in soils through a polythionate pathway.

The sulphur cycle includes an interconnected sets of oxidation-reduction potential of organic and inorganic $\mathrm{S}$ complexes with an alteration in the reduction form of the sulphur from -2 reduced (sulphide) to +6 (sulphate) oxidation state through several common intermediate compounds for example, elemental sulphur $\left(\mathrm{S}^{\mathrm{o}}\right)$, polysulphide, thiosulphate, polythionates and sulfite as shown in figure 1.

\section{Applications of SOB in agriculture}

The microorganisms present in soil improve the plant growth by providing nutrients and defending them against stress and pathogens.

Anandham et al., (2007) demonstrated the use of Rhizobium co-inoculation with the sulfur (S)-oxidizing bacterial strains. Clay-based pellets of Thiobacillus were formulated $(2.5107 \mathrm{cfu} / \mathrm{g}$ pellet$)$ and their efficacy to enhance plant growth was tested in groundnut under pot house and field conditions with sulphur-deficit soil. Experimentation in pot house yielded promising results on groundnut by increasing the plant biomass, nodule number and pod yield and co-inoculation of Thiobacillus sp. $(60 \mathrm{~kg} / \mathrm{ha})$ with Rhizobium under field condition also recorded significantly improvement in all characteristics. Also inoculation of SOB increased the available $S$ of soil from 7.4 to $8.43 \mathrm{~kg} / \mathrm{ha}$ and oil content of groundnut.

Anandham et al., (2008) tested the thiosulfate oxidizing bacteria for their traits related to plant growth promotion. In gnotobiotic experiments, Pandoraeasputorum ATSB28, 
enhanced the primary root length of canola by $166 \%$ and inoculation of Pandoraea sp. strain ATSB30 with RP and thiosulfate significantly increased the water extractable-P (1147 $\mu \mathrm{g} \mathrm{P}$ $\mathrm{g} / \mathrm{RP})$ and bicarbonate extractable-P (1144 $\mu \mathrm{g}$ $\mathrm{P}$ g/RP) on $45^{\text {th }}$ day.

Abhijit et al., (2014) carried out a field experiment to study the effect of sulphur oxidizing strains of Thiobacillus thioxidans along with sulphur to observe the effect of amendments on the yield parameters of mustard (Mustard, var. B-85) At maturity, the average seed yield was $14.5 \%$ higher in $S^{\circ}$ over control which further increased upto $30.6 \%$ along with inoculated sulphur oxidizing strains, while the oil yield was found to be $25.7 \%$ higher in $\mathrm{S}^{\mathrm{o}}$ or gypsum over the control, which increased up to $42 \%$ after 2 nd year with sulphur oxidizing inoculants RS 004.

On an average, the $\mathrm{S}$ increment was recorded $19.1 \%$ with gypsum over the control which further increased up to $22.3 \%$ when amended with sulphur oxidizers.

Chaudhary et al., 2018 also applied SOB with the seeds of mustard for studying their effect on mustard growth.

A total of 15 treatments comprising three controls and six treatments for each bacterium were formulated and different growth parameters were observed. A positive improvement in mustard crop growth with respect to different parameters was recorded after inoculation of SOB.

Inoculations of sulphur oxidizing bacteria with mustard seeds oxidized the reduced sulphur compounds and make them available to plants in sulphate form, which further result in improvement in plant growth parameters such as length, weight, no. of siliquae, seed weight, oil content and chlorophyll content.

\section{Other applications of SOB}

Besides having application in agriculture or for improving plant growth there are reports of many other applications of SOB. SOB has noticeable contribution in maintaining healthy environment. These are applied for bioleaching and extraction of metal from ores, waste water treatment plants, degradation of concrete bridge structures and for bioremediation purposes, etc. An interesting fact of SOB is their adaptability in all kinds of habitats ranging from normal soil, water environments to extreme natural sources like geothermal areas, black shale, volcanic eruptions and acid rock drainage.

\section{Applications of SOB in heavy metal Removal}

The contamination of aquatic sediments with metals is a widespread environmental problem. The conventional technologies used for metal removal has many drawbacks like time consuming, more use of chemicals etc., so environmentally friendly biotechnological approaches (bioleaching) are gaining interest in this field as a promising strategy for the eventual treatment of contaminated sediments and solubilization of heavy metals. Iron and sulphur oxidizing bacteria are exploited for large-scale operations of metal recovery from ores (Seidel et al., 2006; Ilyas et al., 2014). Sulphur oxidizing microorganisms are being used for the extraction of toxic metal ions from contaminated environment by decomposition and erosion methods. Therefore, they can have potential effect on metal retrieval and decontamination of waste products of sewage sludge, industry, coal mine and heavy metal contaminated soils. Acidophilic SOB (Acidithiobacillus ferrooxidans and A. thioosidans) converts the toxic metal sulphides forms to less toxic sulphates (Roy and Roy, 2015). 
The main products of these mechanisms are sulfuric acid and ferric ions. The most commonly used strains for metal removal are Leptospirillum ferrooxidans, Acidithiobacillus ferrooxidans and At.thiooxidans but other species like Aspergillus also known (Dopson and Johnson, 2012; Johnson, 2012) In addition, iron-oxidizing and sulfur oxidizing strains among Archaea have also been identified (Brierley and Brierley, 2013; Vera et al., 2013). For example, thermophilic bacteria, Acidianus brierleyi is a facultatively chemolithoautotrophic, extremely acidophilic Archaeon and aerobic bacteria growing in the presence of $S^{o}$, metal sulphur and ferrous ion.
The solubilization process metal sulphides by these bacteria take place by two independent mechanisms: a 'direct mechanism' (direct enzymatic oxidation of sulphur moiety of metal sulphide) and an 'indirect mechanism' (non-enzymatic metal sulphide oxidation by $\mathrm{Fe}(\mathrm{III})$ ions along with enzymatic (re)oxidation of the resulting $\mathrm{Fe}(\mathrm{II})$ ions; Sand $e t$ al., 2001). SOB also form biofilm with the mineral surface in a contact sub-mechanism, while some planktonic also perform by remain floating in the bulk solution (non-contact submechanism) (Ackil, 2014).

Fig.1 Oxidation-reduction reaction of sulphur compounds

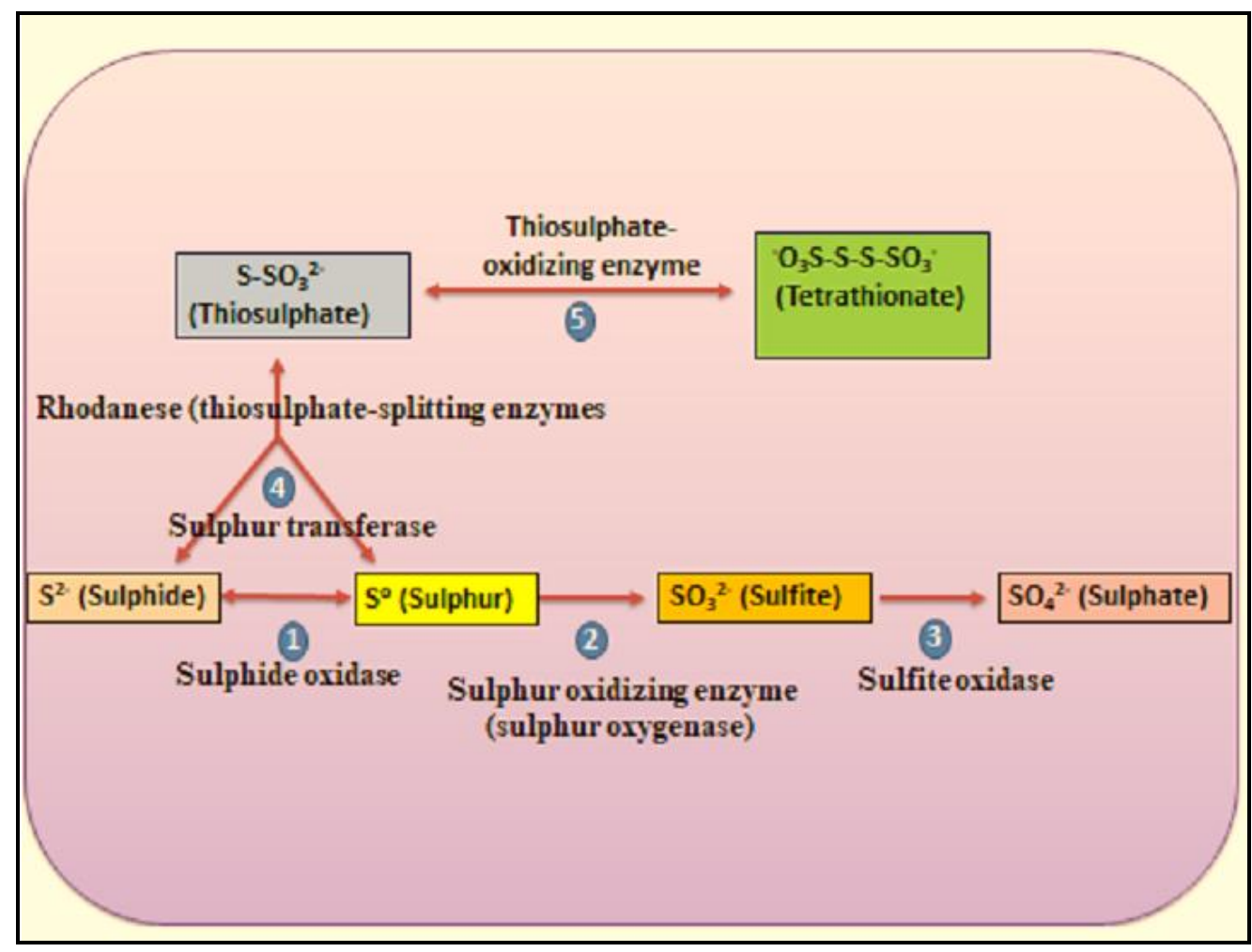

\section{Applications of $\mathrm{SOB}$ in $\mathrm{H}_{2} \mathrm{~S}$ removal}

The sulphur oxidizing bacteria also play an important role in removal of poisonous hydrogen sulphide $\left(\mathrm{H}_{2} \mathrm{~S}\right)$ from the atmosphere. The strong unpleasant smell due to hydrogen sulphide emission is one of the major problems of wastewater treatment plants (WWTP). Also the gas is responsible for atmospheric pollution and corrosion thus affecting human and environmental health (Tang et al., 2009). Three dominant bacterial 
families: Hydrogenophilaceae, Xanthomonadaceae and Spirillaceae found in biofilter packed with marble having acidic $(\mathrm{pH}<3)$ can remove the odour of $\mathrm{H}_{2} \mathrm{~S}$ (Chouari, 2015; Heydarzadeh, 2014).

In other experiment conducted by Lestari, 2016, a packed bed reactor was evaluated for hydrogen sulphide removal by sulfuroxidizing bacteria attached as a biofilm on salak fruit seeds (SFS).

The bacteria were isolated from wastewater sludge biogas plant decreased $\mathrm{H}_{2} \mathrm{~S}$ in biogas from $142.48 \mathrm{ppm}$ to $4.06 \mathrm{ppm}(97.15 \%$ removal efficiency) along with biogas flow rate of $8550 \mathrm{~g} / \mathrm{m}^{3} / \mathrm{h}$ in residence time of $4 \mathrm{~h}$.

Giordano et al., (2015) studied the potential of biological sulphur-oxidizing potential of indigenous sludge of a plant treating tannery wastewater, Italy. It was demonstrated that the use of different fundamental techniques was a basic step in order to detect the large number of SOB components. In addition, the significance of using the primary sludge as inoculum for sulphur oxidizing reactors was ascertained.

\section{Other mixed applications}

Purple sulphur bacteria and other colourless sulphur-oxidizers also used as a part of mixed microbial communities for sewage treatment processes and might also be used in $\mathrm{H}_{2} \mathrm{~S}$ removal.

Sulphur bacteria can also be used for production of biopolymers such as poly $\beta$ hydroxybutyrate and molecular hydrogen. Some sulphate-reducers for example Desulfovibrio desulfuricans are having the capacity of reducing uranium, for concentrating and removal of radioactive uranium (Shreeja, 2016).

\section{Future perspective}

The efficiency of sulphur oxidizing bacteria can be improved to get more and efficient mechanisms for different uses. The limitations like Thiothrix cause problems in the industrial process, needs to be studied and find a solution. Also there is scope of enhancing efficiency of SOB especially in mining activities, where acidophilic sulphur bacteria such as Thiobacillus ferrooxidans, $T$. thiooxidans and $T$. acidophilus, which are being used in the recovery of metals, are too poor for conventional metallurgical extraction. Recoveries of up to $70 \%$ of copper from lowgrade ores can be increase up to maximum potential. It can be concluded that sulphur oxidizing bacteria have enormous potential to metabolize the reduced S-compounds. Due to this they have wide applications in agriculture (crop improvement), maintaining environment, metal removal, tannery waste water treatment by removing $\mathrm{H}_{2} \mathrm{~S}$ etc.

\section{Acknowledgement}

Financial assistance throughout the degree from DST (INSPIRE) Department of Science and Technology, Technology Bhavan, New Mehrauli Road, New Delhi - 110016, is greatly acknowledged by the first author.

\section{References}

Abhijit D., Chandra K.S. and Joseph M. 2014. Evaluation of the efficacy of different sulphur amendments and sulphur oxidizing bacteria in relation to its transformation in soil and yield of mustard (Brassica juncea). Research on Crops. 15(3): 578-584.

Akcil A., Erust C., Ozdemiroglu S., Fonti V. and Beolchini F. 2014. A Review of Approaches and Techniques Used in Aquatic Contaminated Sediments: Metal Removal and Stabilization by Chemical and Biotechnological Processes. Journal of Cleaner

Production. 
doi:10.1016/j.jclepro.2014.08.009. 1-53.

Anandham R., Gandhi P.I., Madhaiyan M. and Sa T. 2008. Potential plant growth promoting traits and bioacidulation of rock phosphate by thiosulfate oxidizing bacteria isolated from crop plants. Journal of Basic Microbiology. 48: 439-447.

Anandhama R., Sridarb P., Nalayinic S., Poonguzhalia M., Madhaiyana T.S. 2007. Potential for plant growth promotion in groundnut (Arachis hypogaea L.) cv. ALR-2 by co-inoculation of sulfuroxidizing bacteria and Rhizobium. Microbiological Research. 162: 139-153.

Camacho A. 2009. Sulfur Bacteria. University of Valencia, Burjassot, Spain. Elsevier Inc. 261-278.

Chaudhary S. 2018. Characterization of sulphur oxidizing bacteria and their effect on growth of mustard (Brassica juncea L.). Ph.D. Thesis published by CCSHAU Hisar.

Chaudhary S., Dhanker R., Tanvi, Goyal S. 2017. Characterization and Optimization of Culture Conditions for Sulphur Oxidizing Bacteria after Isolation from Rhizospheric Mustard Soil, Decomposing Sites and Pit House. International Journal of Biological, Biomolecular, Agricultural, Food and Biotechnological Engineering. 11(6):379383.

Chaudhary S., Tanvi, Verma N. and Goyal S. 2018. Response of sulphur oxidizing bacterial inoculation on growth and yield parameters of mustard (Brassica juncea L.). International journal of Chemical Studies. 6(6): 2452-2457.

Chouari R., Dardouri W., Sallami F., Rais M.B., Denis L.P. and Sghir A. 2015. Microbial Analysis and Efficiency of Biofiltration Packing Systems for Hydrogen Sulfide Removal from Wastewater off Gas. Environmental Engineering Science. 32(2): $1-8$.

Das S.K., Mishra A.K., Tindall B.J., Rainey F.A. and Stackerbrandt, E. 1996. Oxidation of thiosulphate by a new bacterium, Bosea thiooxidans (strain BI-42) gen. nov., sp. nov.: Analysis of phylogeny based on chemotaxonomy and 16S Ribosomal DNA sequencing. International Journal of
Systematic Bacteriology. 46(4): 981-987.

Dopson M. and Johnson D.B. 2012. Biodiversity, metabolism and applications of acidophilic sulfur-metabolizing microorganisms. Environmental Microbiology. 14: 262031.

Giordano P.C., Spennati F., Melone A. and Petroni G. and Verni F., Munz G., Mori G. and Vannini C. 2015. Biological SulfurOxidizing Potential of Primary and Biological Sludge in a Tannery Wastewater Treatment. Water Air Soil Pollution. 226: 39.

Heydarzadeh H., Najafpour G., Ghoreyshi A. and Younesi H. 2014. Hydrogen Sulfide Elimination from Natural Gas by Native Isolated Bacteria from Hot-Spring. EcoTech '14, Kalmar, Sweden, November 2426, 2014.

Ilyas S., Lee J.C. and Kim B.S. 2014. Bioremoval of heavy metals from recycling industry electronic waste by a consortium of moderate thermophiles: process development and optimization. Journal of Cleaner Production. 70:194-202.

Jamal A., Moon Y.S. and Abdin M.Z. 2010. Sulphur-a general overview and interaction with nitrogen. Australian Journal of Crop Science. 4(7): 523-529.

Johnson D.B. 2012. Geomicrobiology of extremely acidic subsurface environments. FEMS Microbiolological Ecology. 81: 212.

Katyal J.L., Sharma K.L. and Srinivas K. 1997. ISI/FAI/IFA Symposium on sulphur in balanced fertilization, 13-14 Feb. New Delhi, India, Proceedings.2/1-2/11.

Kertesz M.A. and Mirleau P. 2004. The Role of Microbes in Plant Sulphur Nutrition. Journal of Experimental Botany. 55: 19391945.

Kuenen J.G. and Beudeker R.F. 1982. Microbiology of bacilli and other souxtotroph, mixotrophs and heterotrophs. Transport Research Society London 298: 473-497.

Lestaria R. A.S., Sediawana W.B., Syamsiaha S., Sartoa, Teixeirac J.A. 2016. Hydrogen sulfide removal from biogas using a salak fruit seeds packed bed reactor with sulfur oxidizing bacteria as biofilm. Journal of 
Environmental Chemical Engineering. 4: 2370-2377.

Prasad R. and Shivay Y.S. 2016. Sulphur in Soil In.Plant and Human Nutrition Proc. Natl. Acad. Sci., India, Sect. B Biol. Sci. DOI 10.1007/s40011-016-0769-0.

Roy S. and Roy M. 2015. Bioleaching of Heavy Metals by Sulfur Oxidizing Bacteria: A Review. International Research Journal of Environment Sciences. 4(9): 1-5.

Sand W., Gehrke T., Jozsa P.G., and Schippers A. 2001. (Bio) chemistry of bacterial leaching-direct vs. indirect bioleaching. Hydrometallurgy. 59(2-3): 159-175.

Scherer H.W. 2009. Review Article-Sulfur in soils. Journal of Plant Nutrition and Soil Science. 172: 326-335.

Seidel H., Wennrich R., Hoffmann P. and Löser C. 2006. Effect of different types of elemental sulfur on bioleaching of heavy metals from contaminated sediments. Chemosphere. 62(9): 1444-1453.

Shi J., Lin H., Yuan X. and Zhao Y. 2011. Isolation and characterization of a novel sulphur oxidizing chemolithoautotroph Halo Thiobacillus from $\mathrm{Pb}$ polluted paddy soil. African Journal of Biotechnology. 10(20): 4121-4126.

Shreeja D. 2016. Sulphur: Sources, Distribution and Forms. Soil Science » Soil » Nutrient Elements ») Sulphur 2016.

Singh C. 2001. Rapeseed and mustard. Principles of agronomy. Oxford and IBH Publishing Co. Pvt. Ltd., 22-A, Sarojani Naydu Marg, Allahabad (U.P.) India.

Skiba U. and Wainwright M. 1984. Oxidation of elemental sulphur in coastal dune sands and soils. PI. Soils. 77: 87-95.

Starkey R. L. 1935. Isolation of some Bacteria which Oxidize Thiosulfate. Soil Science, 39:197-219.

Starkey R.L. 1934. Cultivation of organisms concerned in the oxidation of thiosulphate. Journal of Bacteriology. 28: 365-386.

Tandon H.L.S. and Messick D.L. 2002. Practical Sulphur Guide Book. The Sulphur Institute, Washington, Dc.

Tang K., Baskaran V. and Nemati M. 2009. Bacteria of the sulphur cycle: an overview of microbiology, biokinetics and their role in petroleum and mining industries. Biochem. Eng. J. 44: 73.

Vidyalakshmi R., Paranthaman R. and Bhakyaraj R. 2009. Sulphur Oxidizing Bacteria and Pulse Nutrition - A Review. World Journal of Agricultural Sciences 5(3): 270-278.

Wainwright W. 1984.Sulphur oxidation in soils. Advances in Agronomy, 37: 349-396.

\section{How to cite this article:}

Suman Chaudhary, Tanvi, Rinku Dhanker and Sneh Goyal. 2019. Different Applications of Sulphur Oxidizing Bacteria: A Review. Int.J.Curr.Microbiol.App.Sci. 8(11): 770-778.

doi: https://doi.org/10.20546/ijcmas.2019.811.091 